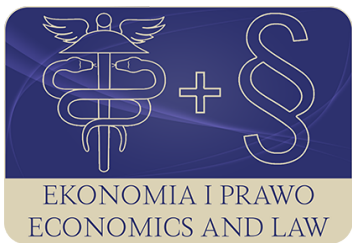

EKONOMIA I PRAWO. ECONOMICS AND LAW

Volume 16, Issue 3, September 2017

p-ISSN 1898-2255, e-ISSN 2392-1625

www.economicsandlaw.pl

ECONOMICS AND LAW

ORIGINAL ARTICLE

received 13.06.2017; revised 25.09.2017; accepted 30.09.2017

Citation: Janik, B. (2017). Value-based banking in Central and Eastern Europe countries: ecological point of view. Ekonomia i Prawo. Ecomomics and Law, 16(3): 313-324. doi:10.12775/EiP.2017.022.

\title{
Value-based banking in Central and Eastern Europe countries: ecological point of view
}

\author{
BOGNA JANIK \\ WSB University in Poznań, Institute of Finance, \\ ul. Powstańców Wielkopolskich 5, 61-895 Poznań, Poland \\ ๑bogna.janik@wsb.poznan.pl
}

\begin{abstract}
Motivation: Banks play an important role connected with financing pro-ecological investments made by enterprises. They support pro-ecological activities of the entities applying for financing or offer saving/investment products relating to the environmental impact. In terms of their external pro-ecological activities there can be distinguished two groups of banks. The first group offers a wide selection of products and pro-ecological services as well as uses the tools of environmental risk management. The second group concentrates on offering selective products and services as well as is.

Aim: The main objective of the study is to identify and assess some chosen aspects of ecological activities of the banks listed on Stock Exchanges in CEE countries and included in sectoral indices and sustainable indices such as: RESPECT, CEERIUS and VONIX. The scope of this analysis encompasses selected dimensions illustrating banks' activities in terms of environmental protection. The analysis of the investigated dilemma was based mainly on the desk research of digital and documentary sources.

Results: The results indicate relatively huge differences across environmental care in value-based banks compared to conventional banks, and small differences between value-based banks.
\end{abstract}

Keywords: environmental care; social banking; sustainable indices; value-based banking JEL: G21; Q01; Q56 


\section{Introduction}

The contemporary financial system is too big, too complicated and too remote from the real economy. Simultaneously, both internal and external stakeholders concentrate thoughtlessly too much on short-term profits without any consideration given to long-term social or environmental effects, which results in rapid distortions of the system as such. It has already been well proven by the Global Financial Crises of 2007, which devastated not only the financial market but also the real economy, and whose effects will be experienced even in the future also in the political sphere. Hence the question arises: how should the financial system evolve? It seems that the answer is explicit. It should be driven by attitudes and values which support the welfare of individuals and simultaneously guarantee sustainable economy. The key link of each financial system is the banking system. In terms of the discussed changes, the banking system should be based on value based banking, whose managing and operating systems encompass its clients and other interested parties. It is a key figure upon which new institutional, social and economic solutions can be built. Value based banking is aimed at developing value based economy which considers our ecosystem as the heritage of the entire humanity.

The notion of value based banking, however, in today's world sounds like an oxymoron, a combination of words which have no right to co-exist. It probably results from the fact that banks are usually perceived as links of the market financial system and mostly assigned purely market connotations. However, the question is: do placing banking entities within the banking system and limiting their activities by the application of certain precautions or recommendations make the banks obligated to realize social goals? It is common knowledge that banks especially commercial ones play two contradictory roles. On the one hand, their activities are aimed at profit maximization, on the other hand, as the owner of national deposits, they are obliged to protect them from any form of destabilization. Nevertheless, it does not mean that they realize social goals but they try to achieve only stabilization ones. So, what does the realization of social goals mean? How can the social character of banking entities be defined?

F. de Clerck (2009, p. 213) estimated that the definition of social banking is not clear because 'social, ethical, alternative sustainable development and solidarity banking and finance are denominations that are currently used to express particular ways of working with money based on non-financial deliberations. A precise and unified definition of these types of finance as such is not available and perhaps not possible because of the different traditions from which the ethical finance actors have emerged'.

The proper interpretation of social banking will be probably the object of continuous search and presumably it will evolve as well. However, for the purpose of the research, to reach the assumed goal, namely: to identify and assess some chosen aspects of ecological activities of the banks listed on Stock Exchanges in CEE countries, the definition by J. Niven at the Global Alliance from Bank- 
ing on Values (GABV) was taken. He defines the goals of social banks as follows: "to make an impact directly — by increasing our lending and investing to people and organizations that benefit people, the environment and culture. Making an impact by influencing others indirectly, both by showing that a different approach to banking is both possible and necessary and by actively engaging in important wider discussions about the future of the financial industry (J. Niven personal interview in O. Weber and S. Remer (2011, p. 2)).

S. Scheire and S. de Maertelaere (2009) differentiated two groups of social banks classified according to the geographical criterion into poverty alleviation banks (in the South) and ethical banks (in the North). They indicated some fundamental differences between the two groups both in their mission statement and in the organizational structure.

R. Milano (2011, p. 31) classified social banks according to their mission statement enlarging, by the same token, the range of the entities. According to the author, there are four groups of social banks:

- banks and other similar institutions, which continue social banking activities (e.g. reflected in social responsible indices, union credits);

- banks and other similar institutions, which travel a new road from an economic point of view (e.g. members of FEBEA, INAISE, GABoV, socially responsible investment funds);

- banks and similar institutions, which open new markets (microcredit and microfinance in general) (e.g. members of FEBEA, INAISE, GABV, socially responsible investment funds);

- banks especially engaged in charitable activities (e.g. children's banks The Children's Development Bank, charity foundations).

Referring to the above classification, a wide spectrum of activities of the so called social banks is visible. The author refers this name strictly to banks and other financial institutions operating on the basis of different legal foundations. Apart from the entity division, there is also the object division in which financial institutions may be called typically social institutions as well as those which combine the features of social and commercial banks. The above divisions may reflect customary or cultural differences. The culture consists of customary beliefs and values that ethics, religious and social groups transmit fairly unchanged from generation to generation.

\section{Literature review}

As far as innovations are concerned (including eco innovations) academic researchers have paid much attention to industrial product development and less so to services, including financial ones (Vermeulen, 2001). The publications, by the authors mentioned below, discussing the development of new financial services are more of ordering rather than evaluating nature (McMillan et al., 1985, pp 75-86; Thwaites, 1992, pp. 303-313.; Edgett \& Parkinson, 1994, pp. 24-38; Cooper et al., 1994, pp 281-299). It was M. Jeucken (2004) who dis- 
cussed the idea of intermediaries (banks) by presenting the model of their evaluation in terms of sustainability, and by putting greater emphasis on ecological activities.

Banks support pro-ecological activities of the entities applying for financing or offer saving/investment products relating to the environmental impact. In terms of their external activities there can be distinguished two groups of banks. The first group includes these banks whose ecological activity is provided in strategic documents and it suits their core activity, whereas the second group encompasses such banks, which so far have only built the image of eco-friendly banks. The first group offers a wide selection of products and pro-ecological services as well as uses the tools of environmental risk management. The second group concentrates on offering selective products and services as well as is active in the area of pro-ecological marketing.

The interest in pro-ecological projects of bank clients is growing as well as bank offers. Such interest arouses from at least two reasons. First of all, high standards of environmental protection impose on enterprises searching for such products which are to solve ecological problems. Here, the related costs should not be excluded. Although the simple economic logic suggests that restrictive ecological standards should increase the costs of enterprise activities, and consequently influence negatively their profitability, still the growing number of empirical evidence indicates a positive relation between the enterprise value and its positive influence on the environment. R. Klassen and C. McLaughlin (1996, pp. 1199-1214) while conducting an event study found considerably abnormal returns, the moment an enterprise received a reward for eco-innovation, and significant negative returns after an environmental crisis. G. Dowell et al. (2000, pp. 1059-1074) stated that corporations seated in the United States and adopting restrictive environmental standards have a much higher market value than those with less restrictive environmental standards. The second reason is connected with following the rules of environmental protection as a common good which should be preserved for future generations. Therefore, the growing social consciousness makes entrepreneurs search for pro-ecological solutions.

Various publications state that with increased awareness of ecological risk, regulators have responded with a program with regulatory reforms arguing that an ecological modernization can result in both economical and environmental benefits (Murphy \& Gouldson, 2000, pp. 33-44).

\section{Methods}

The object of the research included banks listed on the Stock Exchanges of Central and Eastern Europe such as: Warsaw Stock Exchange, Vienna Stock Exchange, Bucharest Stock Exchange, Bulgarian Stock Exchange, Prague Stock Exchange, Budapest Stock Exchange (no bank was listed on the Lublajana Stock Exchange in the analyzed period). In order to select a uniform research sample, 
24 banks were chosen among 26 banks. The remaining two banks are listed simultaneously on mature markets and have a much bigger experience in conducting environmental activities, hence adopt much higher standards. Some of the analyzed banks are concurrently listed in sustainability indices: RESPECT (5 banks), VONIX (2 banks), CEERIUS (2 banks). One bank is listed in both RESPECT and CEERIUS indices.

The analysis involved the following set of activities within the scope of environmental issues:

- environmental reporting and certification;

- environmental care in practice: reporting policy, objectives, data, products/ services.

In order to realize properly the research goal mentioned earlier, a research method was developed, i.e. content analysis which is to analyze the content of websites. The study was preceded by a profound examination of available literature. Thanks to this method, the message of particular companies referring to environmental activities was examined and evaluated. In particular, the type of published information pursuant to the criteria specified for the research purposes. The methodology by M. Jeucken (2004, pp. 389-392) with a slight modification was used as a model'. So, only the scope of research was limited. The original approach by Jeucken encompassed a much greater range, namely socially responsible practices (including the environmental one). The paper included only the environmental dimension. Therefore the first modification resulted in further consequences, i.e. the adjustment of weights to particular activities pursuant to the ecological approach. Simultaneously, the research was adjusted to the current conditions of Central and Eastern Europe market, including the current phase of developing pro-ecological activities on the market. The original methodology applied by M. Jeucken classifies the elements of evaluation into five groups, each weighted by its share depending on the expected effect (the power of influence on socially responsible activities undertaken by banks).

The distinguished groups include:

- group I: communication (with the surrounding) — weight 10\%;

- group II: availability of published information - weight 25\%;

- group III: availability of financing (understood as the principles of evaluating credit rating and risk assessment for a bank) — weight 15\%;

- group IV: availability of socially responsible financial products - weight $40 \%$;

- group V: social issues and charity activities — weight $10 \%$.

Table 1. presents the modification method and its justification.

As a result of adjusting a selected research approach, I defined four main groups of criteria on the basis of which I prepared sub-rankings in the next stage as well as the main ranking of the analyzed banks (table 2). As it is clearly

${ }^{1}$ A similar model was earlier applied by B. Janik and K. Kołodziejczyk (2016, pp 1320) in the analysis of the banks listed on the Warsaw Stock Exchange. 
noticeable, the greatest attention was put to the criterion 'generic published information' (40\%), which consisted mainly of quantitative and qualitative data referring to internal and external activities as well as the goals of the companies in terms of 'environmental care'. A smaller attention (30\%) was given to green products available on the market, however, I limited ourselves only to: time deposits, investment funds, loans and credits, leasing and 'other products'. The third considered criterion was 'communication' (20\%). This highly demanding criterion was based on three components: environmental policy, environmental reports and ISO 14001, 2600 standards or EMSs. The last criterion was 'social issues and charity', which consisted of the support for educational and scientific activities, activities conducted by higher education institutions, and activities for local societies as well as the level of employees' involvement in environmental projects.

Unfortunately, chaos and lack of systematization of the website contents hosted by certain banks was an obstacle met while realizing research assumptions, in particular in terms of social responsibility, including the reference to the natural environment.

\section{Results}

The research results were discussed pursuant to the classification of the criteria presented in table 2. In terms of generic published information, there has appeared a contrast between banks listed within socially responsible indices and the remaining banks. A special attention, however, should be also put on trans-border activities of the banks where good practices in terms of environmental protection are being introduced jointly in all countries. Here, it refers especially to one bank (ERSTE GROUP BANK AG) listed on the majority of stock exchanges in Central and Eastern Europe. On the other hand, the results of another group are worth paying attention to (9 banks out of 24 analyzed), namely these banks which obtained zero points. The analysis shows also the third characteristic group, which as a matter of fact gained some points but it was only due to a few detailed criteria.

The second main criterion took into account green products offered by the banks. There were 5 detailed criteria (table 2 ) enumerated. The current offer, however, did not seem to be outstanding. Only green investment funds enjoy a relatively rich offer among the research sample (1l banks). Still, it should be emphasized that the main contribution ought to be assigned to investment funds as such since banks only distribute their offers. A relatively huge number of banks offered also loans and credits supporting pro-ecological activities (5 banks). In the case of the remaining products, only one bank offered pro-ecological deposits and one pro-environmental leasing.

The most demanding challenge for the analyzed banks seemed to be the communication of their environmental activities. In these terms we can say about a peculiar dualism among the banks. There are the leaders who in more or less 
formalized way work on their socially responsible image including their engagement in natural environment issues. There are also banks which do not show any proper interest in social responsibility, including ecological one. As far as the leaders are concerned, the moment the research was being conducted, two banks included in the RESPECT Index, one in the CEERIUS Index and one in the VONIX Index obtained a prestigious certificate ISO 14001, which certifies the implementation of a formalized system of environmental management in the company. The remaining banks, though active in a selected criterion area, were proud mostly of their environmental reports, most of all within social responsibility sphere. Only six banks communicated their own pro-environmental activities on the basis of environmental reports, emphasizing the importance of environmental issues in their own activity. It is also worth mentioning that a considerable number of banks (7 banks including 4 listed within socially responsible indices) informed about passing their own environmental policies by publishing at least the copies of proper documents on their websites.

In terms of the support for pro-environmental social issues and charity, a considerable majority of the banks showed only a slight activity.

Table 3 presents a bank ranking based on earlier defined criteria. This comparison clearly indicates a significant differentiation in the approach to environmental issues. Among the analyzed group, three bank groups were distinguished: Active Banks $(\mathrm{AcB})-8$ banks, Preventive Banks $(\operatorname{PrB})-7$ banks, Passive Banks $(\mathrm{PaB})-9$ banks. The first group consistently faces the challenges of green economy. Their activities do not take a 'stock' character but can be characterized by their systematic and growing degree of formality. Among these banks as many as 5 are also listed in socially responsible indices. One bank operates strictly to support pro-ecological activities (BOS Bank) and the remaining banks are a part of the capital group dispersed in the majority of CEE countries and, by the same token, they have unified environmental standards (ERSTE GROUP BANK AG). The second group includes the banks which notice the importance of this area, proved by the attempts of undertaking pro-environmental activities, however, they are rather at the starting point towards more decisive undertakings. Nonetheless, the estimates are poor for the third group. These banks make an impression of being completely indifferent towards environmental issues.

The research indicated that green products offered by these banks are still more an exception rather than a rule in the offer available on the market.

\section{Conclusion}

The research results indicate some attempts banks make to conduct environmental protection activities in CEE countries. The scope of the analysis includes only the banks listed on Stock Exchanges. It means that the research encompasses only these entities that should show standards higher than their proper counterparts whose stocks are not listed on Stock Exchanges. It results from 
the transparency rule, the need of strong communication with stakeholders and taking care of their own image. Among active banks, the majority is listed within socially responsible indices ( 5 banks). Only three banks listed within socially responsible indices were classified into neutral banks and none into passive banks. Also, system-like activities conducted by the banks to protect the environment were noticed within one capital group. Although one of the capital group banks (Erste Group Banks) is listed within the socially responsible index, i.e. VONIX, high standards are followed by each bank. It may mean that the requirements set by the index itself were not the only reason for their implementation. Moreover the conducted research does not exhaust the subject as such. From the cognitive perspective, the analyses of evolution or changes in the income-maximization axiom for stakeholders to a multi-criteria optimization considering such factors as income and concern about social or ecological values, all seem interesting. Still, the conflict between the responsibility towards a society and effective use of resources banks have at their disposal, though is somehow alleviated, remains crucial.

\section{References}

Cooper, R.G., Easingwood, C.J., Edgett, S., Kleinschmidt, E.J., \& Storey, C. (1994). What distinguishes the top performing new products in financial servicies. Journal of Product Innovation Management, 11(4). doi:10.1111/1540-5885.1140281.

De Clerck, F. (2009). Ethical banking. In L. Zsolnai, Z. Boda, \& L. Fekete (Eds.), Ethical prospects: economy, society, and environment. Berlin-Heidelberg-New York: Springer. doi:10.1007/978-1-4020-9821-5_10.

Dowell, G., Hart, S., \& Yeung, B. (2000). Do corporate global environmental standards create or destroy market value? Management Science, 46(8). doi:10.1287/mnsc.46.8.1059.12030.

Edgett, S., \& Parkinson, S. (1994). The development of new financial services: identifying determinants of success and failure. International Journal of Service Industry Management, 5(4). doi:10.1108/09564239410068689.

Janik, B., Kołodziejczyk, K., (2016). Ecological and eco-innovative activities of the banks. Perspectives of Innovations, Economics and Business, 16(1). doi:10.15208/pieb.2016.02.

Jeucken, M. (2004). Sustainability in finance: banking on the planet. Delft: Eburon Academic Publishers.

Klassen, R., McLaughlin, C. (1996). The impact of environmental management on firm performance. Management Science, 42(8). doi:10.1287/ mnsc.42.8.1199.

McMillan, I., McCaffery, M.L., \& Van Wijk, G. (1985). Competitor's response to easily imitated new products: exploring commercial banking product introductions. Strategic Management Journal, 6(1). doi:10.1002/ smj.4250060106. 
Milano, R. (2011). Social banking. In O. Weber, \& S. Remer (Eds.), Social banking and the future of sustainable finance. London-New York: Routledge, Taylor \& Francis Group. doi:10.4324/9780203827871.

Murphy, J., \& Gouldson, A. (2000). Environmental policy and industrial innovation: integrating environment and economy through ecological modernization. Geoforum, 31(1). doi:10.1016/s0016-7185(99)00042-1.

Scheire, C., \& de Maertelaere, S. (2009). Banking to make a difference (Preliminary Report), Artevelde: Artevelde University College.

Thwaites, D. (1992). Organizational influences on the new product development process in financial services. Journal of Product Innovation Management, 9(4). doi:10.1111/1540-5885.940303.

Vermeulen, P.A.M. (2001). Organizing product innovation in financial services. Nijmegan: Nijmegen University Press.

Weber, O., \& Remer, S. (2011). Social banking: introduction. In O. Weber, \& S. Remer (Eds.), Social banking and the future of sustainable finance. London-New York: Routledge, Taylor \& Francis Group. doi:10.4324/9780203827871.

\section{Acknowledgements}

Author contributions: author has given an approval to the final version of the article..

Funding: this research was fully funded by the WSB University in Poznan, Institute of Finance statutory sources.

Note: the results of this study were presented at 9th International Conference on Applied Economics Contemporary issues in Economy (June 22-23, Torun, Poland). 


\section{Appendix}

Table 1.

The modification method and its justification according to M. Jeucken's Model

\begin{tabular}{|c|c|c|c|c|}
\hline Groups & $\begin{array}{l}\text { Share in M. Jeucken's } \\
\text { model (in \%) }\end{array}$ & $\begin{array}{l}\text { Change } \\
\text { (in \%) }\end{array}$ & $\begin{array}{l}\text { Share after } \\
\text { the change } \\
\text { (in \%) }\end{array}$ & Justification \\
\hline Communication & 10 & +10 & 20 & $\begin{array}{c}\text { According to M. Jeucken's Model, } \\
\text { the biggest share in this group was assigned } \\
\text { to ecological activities (environmental } \\
\text { reports, policy) }\end{array}$ \\
\hline $\begin{array}{l}\text { Generic } \\
\text { published } \\
\text { information }\end{array}$ & 25 & +15 & 40 & $\begin{array}{l}\text { According to M. Jeucken's Model, the big- } \\
\text { gest share in this group was assigned to eco- } \\
\text { logical activities (quantitative and qualitative } \\
\text { data and objectives of internal and external } \\
\text { environmental care) }\end{array}$ \\
\hline $\begin{array}{l}\text { Generic } \\
\text { Financing }\end{array}$ & 15 & -15 & 0 & $\begin{array}{l}\text { Only one bank conducted this sort of ac- } \\
\text { tivity (specializing in financing ecological } \\
\text { activities) }\end{array}$ \\
\hline Special products & 40 & -10 & 30 & $\begin{array}{l}\text { The points was limited due to an insufficient } \\
\text { product offer of the banks in Central } \\
\text { and Eastern Europe countries }\end{array}$ \\
\hline $\begin{array}{l}\text { Social issues } \\
\text { and charity }\end{array}$ & 10 & 0 & 10 & No changes \\
\hline
\end{tabular}

Source: Own preparation. 
Table 2.

Environmental care (EC) of the banks listed on stock exchanges of CEE countries main and detailed criteria (between Results and Conclusions)

\begin{tabular}{|c|c|c|c|c|c|c|c|}
\hline \multicolumn{8}{|c|}{ Main criteria with weighted means } \\
\hline \multicolumn{2}{|c|}{$\begin{array}{l}\text { Generic published infor- } \\
\text { mation }\end{array}$} & \multicolumn{2}{|l|}{ Products } & \multicolumn{2}{|c|}{ Communication } & \multicolumn{2}{|c|}{ Social issues and charity } \\
\hline Share $40 \%$ & Points & Share $30 \%$ & Points & Share $20 \%$ & Points & Share $10 \%$ & Points \\
\hline $\begin{array}{l}\text { Quantitative data } \\
\text { about Internal EC }\end{array}$ & $4 \mathrm{p}$ & $\begin{array}{l}\text { Time deposits } \\
\text { (investment/ } \\
\text { structured) with } \\
\text { the allocation } \\
\text { of a part of or } \\
\text { all the resources } \\
\text { in pro-ecological } \\
\text { solutions }\end{array}$ & $3 p$ & $\begin{array}{l}\text { Environmental } \\
\text { policy }\end{array}$ & $4 \mathrm{p}$ & $\begin{array}{l}\text { Support for edu- } \\
\text { cational, scientific } \\
\text { and higher educa- } \\
\text { tion institution } \\
\text { activities }\end{array}$ & $2 p$ \\
\hline $\begin{array}{l}\text { Qualitative data } \\
\text { about Internal EC }\end{array}$ & lp & $\begin{array}{l}\text { Investment } \\
\text { funds (shares } \\
\text { distribution } \\
\text { of pro-ecological } \\
\text { funds) }\end{array}$ & $3 p$ & $\begin{array}{l}\text { Environmental } \\
\text { reporting }\end{array}$ & $1-5 p$ & $\begin{array}{l}\text { Activities for local } \\
\text { communities }\end{array}$ & $2 \mathrm{p}$ \\
\hline $\begin{array}{l}\text { Objectives for } \\
\text { Internal EC for } \\
\text { the Future }\end{array}$ & $3 p$ & $\begin{array}{l}\text { Loans/credits for } \\
\text { the undertakings } \\
\text { contributing } \\
\text { to the limitation } \\
\text { of enterprises/ } \\
\text { institutions' influ- } \\
\text { ence and individ- } \\
\text { uals (microloans/ } \\
\text { credits) } \\
\text { on the pollution } \\
\text { of water, air } \\
\text { and soil }\end{array}$ & $3 p$ & $\begin{array}{l}\text { ISO } 14001, \text { ISO } \\
26000 \text { or EMSs }\end{array}$ & $6 \mathrm{p}$ & - & - \\
\hline $\begin{array}{l}\text { Quantitative data } \\
\text { about External } \\
\text { EC }\end{array}$ & $2-4 p$ & Leasing (as above) & $3 p$ & - & - & - & - \\
\hline $\begin{array}{l}\text { Qualitative data } \\
\text { about External } \\
\text { EC }\end{array}$ & lp & $\begin{array}{l}\text { Other products/ } \\
\text { services }\end{array}$ & $3 p$ & - & - & - & - \\
\hline $\begin{array}{l}\text { Objectives for } \\
\text { External EC for } \\
\text { the Future }\end{array}$ & $3 p$ & - & - & - & - & - & - \\
\hline
\end{tabular}

Source: Own preparation based on Jeucken (2004, pp. 389-392). 
Table 3.

The ranking of the banks based on selected main criteria (between Results and Conclusions)

\begin{tabular}{|c|c|c|c|c|c|c|c|}
\hline \multirow[t]{2}{*}{ Bank } & \multirow[t]{2}{*}{$\begin{array}{l}\text { Country/SR } \\
\text { Index }\end{array}$} & $\begin{array}{l}\text { Informa- } \\
\text { tion type }\end{array}$ & Products & $\begin{array}{l}\text { Commu- } \\
\text { nication }\end{array}$ & $\begin{array}{c}\text { Social } \\
\text { issues } \\
\text { and char- } \\
\text { ity }\end{array}$ & \multirow[t]{2}{*}{$\begin{array}{l}\text { Sum } \\
\text { of points }\end{array}$} & \multirow[t]{2}{*}{$\begin{array}{l}\text { Ranking/ } \\
\text { Group }\end{array}$} \\
\hline & & $\begin{array}{c}\text { Share } \\
40 \%\end{array}$ & $\begin{array}{l}\text { Share } \\
30 \%\end{array}$ & $\begin{array}{l}\text { Share } \\
20 \%\end{array}$ & Share 10\% & & \\
\hline Alior Bank & PL & 0.0 & 0.0 & 0.0 & 0.0 & 0.0 & 15/III \\
\hline Bank Millennium & $\begin{array}{l}\text { PL/RESPECT/ } \\
\text { CEERIUS }\end{array}$ & 5.6 & 1.8 & 0.6 & 0.3 & 8.3 & $5 / \mathrm{I}$ \\
\hline OTP & HU/CEERIUS & 0.8 & 1.8 & 2.6 & 0.0 & 5.2 & 7/II \\
\hline BOS SA & PL & 4.4 & 2.7 & 1.8 & 0.5 & 9.4 & $4 / \mathrm{I}$ \\
\hline Idea Bank & PL & 0.0 & 0.0 & 0.0 & 0.0 & 0.0 & III \\
\hline BZ WBK & PL/RESPECT & 3.6 & 1.8 & 0.8 & 0.5 & 6.7 & 6/I \\
\hline Getin Holding & PL & 0.0 & 0.0 & 0.0 & 0.0 & 0.0 & 15/III \\
\hline Getin Noble Bank & PL & 0.0 & 0.0 & 0.0 & 0.0 & 0.0 & 15/III \\
\hline Handlowy & PL/RESPECT & 5.2 & 1.8 & 2.2 & 0.5 & 9.7 & 3/I \\
\hline ING Bank Slaski & PL/RESPECT & 6.4 & 0.9 & 2.6 & 0.5 & 10.4 & $1 / \mathrm{I}$ \\
\hline MBank & PL & 3.2 & 0.9 & 0.6 & 0.0 & 4.7 & 8/II \\
\hline Pekao & PL/RESPECT & 0.8 & 0.9 & 0.2 & 0.2 & 2.1 & 14/II \\
\hline Pko BP & PL & 3.2 & 0.9 & 0.0 & 0.0 & 4.1 & 9/II \\
\hline $\begin{array}{l}\text { Raiffeisen Bank } \\
\text { Internat Ag }\end{array}$ & AT/VONIX & 2.0 & 0.9 & 0.6 & 0.0 & 3.5 & 11/II \\
\hline BKS Bank & AT/VONIX & 2.0 & 3.6 & 0.0 & 0.2 & 3.8 & 10/II \\
\hline Erste Group Bank Ag & AT/VONIX & 6.4 & 0.9 & 3.0 & 0.0 & 10.3 & 2/I \\
\hline Erste Group Bank Ag & $\mathrm{CZ}$ & 6.4 & 0.9 & 3.0 & 0.0 & 10.3 & $2 / \mathrm{I}$ \\
\hline Komercni Banka & CZ & 2.4 & 0.0 & 0.2 & 0.0 & 2.6 & 12/II \\
\hline Moneta Money Bank & $\mathrm{CZ}$ & 0.0 & 0.0 & 0.0 & 0.0 & 0.0 & 15/III \\
\hline Erste Group Bank Ag & RU & 6.4 & 0.9 & 3.0 & 0.0 & 10.3 & 2/I \\
\hline $\begin{array}{l}\text { Banca Comerciala } \\
\text { Capatica }\end{array}$ & RU & 0.0 & 0.0 & 0.0 & 0.0 & 0.0 & 15/III \\
\hline $\begin{array}{l}\text { FHB Mortgage Bank } \\
\text { Co Plc }\end{array}$ & $\mathrm{HU}$ & 0.0 & 0.0 & 0.0 & 0.0 & 0.0 & 15/III \\
\hline $\begin{array}{l}\text { CB Central } \\
\text { Cooperative Bank }\end{array}$ & BG & 0.0 & 0.0 & 0.6 & 0.0 & 0.0 & 15/III \\
\hline $\begin{array}{l}\text { CB First Investment } \\
\text { Bank Ad }\end{array}$ & BG & 0.0 & 0.0 & 0.0 & 0.0 & 0.0 & 15/III \\
\hline
\end{tabular}

Notes:

Selected bank groups: III - 0.00-2.14 environmental passive banks (PaB); II - 2.14-6.31 environmental preventive banks (PrB); I - 6.31-14.40 environmental active banks (AcB).

Selection to the group (grouping using the cluster analysis, $k$-means):III -2.14 and less $[\mathrm{X}<$ means -0.5 * standard deviation]; II $-2.14-6.31$ [means $-0.5 *$ standard deviation $<\mathrm{X}<$ means +0.5 * standard deviation]; I - above 6.31 [means $+0.5^{*}$ standard deviation $<$ X]; right-enclosed compartments.

Source: Own preparation. 